\title{
Attestation of assumptions about random error of the regression model
}

\section{MiriAM ANDREJIOVÁ}

\section{ABSTRACT.}

The article deals with the regression model of functional dependency on impact force from height of falling and weight of ram for selected conveyor belt. Main part of the article is devoted to the analysis of random error, mainly verifying the conditions of independence, normality and homoscedasticity of residuals.

Department of Applied Mathematics

TECHNICAL UNIVERSITY OF KoŠICE

FACULTY OF MECHANICAL ENGINEERING

LETNÁ 9, 040 00, Košice, SLOVAK RePUblic

E-mail address: miriam.andrejiova@tuke.sk 